\section{Digital Interpretive Media Usage in Cultural HERITAGE SITES AT YOGYAKARTA}

\author{
Ulka Chandini Pendit, Syamsul Bahrin Zaibon*, Juliana A. \\ Abubakar
}

School of Multimedia Technology \& Communication, Universiti Utara Malaysia, Kedah, Malaysia
Article history

Received

3 December 2013

Received in revised form

2 July 2014

Accepted

25 November 2014

${ }^{*}$ Corresponding author syamsulbahrin@uum.edu.my

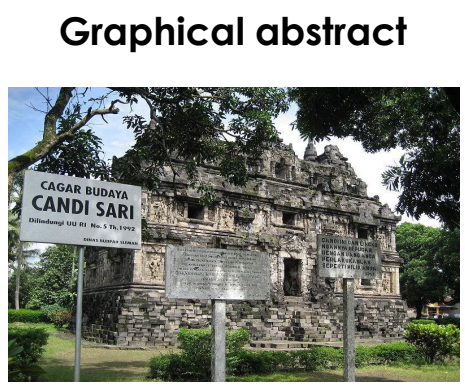

\begin{abstract}
Cultural heritage is the asset of tourism industry to attract tourist for visiting a country. Cultural heritage needs to be conserved in order to prolong the life from being deterioration. However, conservation needs huge financial cost and this reason becomes the major obstacles for cultural heritage to be maintained its existence in a country. Nowadays, digital cultural heritage conservation is alternatively utilized as it reduces the cost of conservation in the form of digital interpretive media such as video, animation, 3D simulation, virtual reality, and augmented reality. Therefore, this study attempted to seek about the availability of digital interpretive media at cultural heritage sites through a survey. This paper presents the findings of availability level of digital media in the heritage sites in Yogyakarta, Indonesia. The findings show that the availability of digital media in Yogyakarta cultural heritage sites are mostly in traditional media types such as signs, brochures, maps, leaflets, and books. In attracting tourist, it is suggested that the cultural heritage sites should be provided with more advance interpretive media, namely computer simulations; personal stereo guided tours, virtual reality, and recently augmented reality as a way to conserve cultural heritage information and values.
\end{abstract}

Keywords: Digital conservation, interpretive media, virtual heritage

(C) 2015 Penerbit UTM Press. All rights reserved

\subsection{INTRODUCTION}

Heritage defines the identity of a nation which is inherited from the ancestors that needs to be preserved and conserved. Based on the types of attraction, heritage can be classified into natural heritage (national parks, natural protected areas), living cultural heritage (fashions, food, customs), built heritage (historic buildings, monuments, ancient ruins), industrial heritages (textiles, coal), personal heritage (cemeteries, religious sites) and dark heritage (places of atrocity, symbol of death and pain) [1]. Further, cultural heritage is defined as "a place, locality, natural landscape, settlement area, architectural complex, archaeological site or standing structure that is recognized and often legally protected as a place of historical and cultural significance" [2]. Cultural heritage is the asset of national tourism to attract tourist for visiting the country. In Indonesia, it boosts national tourism revenue with USD 8.4 billion in 2011 that contributes nearly to $5 \%$ of GDP [3]. This is one of the strong reasons why cultural heritage needs to be conserved and preserved for the next generation.

Further, cultural heritage needs to be conserved in order to prolong the life and basic function of historical building from deterioration [4]. However, conservation is hard to be implemented since it needs huge financial cost while there is still hunger and poverty in this world [5]. These become the major obstacles for heritage to maintain its existence in society [6].

The problem of conservation and funding may be solved by using non-interpretive media as the tool of conservation. This is possible for non-interpretive media which uses digital media as representation to 
present information to visitors. Therefore, the objective of this study is to determine the availability and usage of digital media at Yogyakarta cultural heritage sites. Yogyakarta is chosen as the case study because it is the famous region for the large number of culture heritage sites in Indonesia.

The next section of this paper explains about the interpretive media in general and non-personal interpretive media in particular. The third section tells about the AR usage for conservation in cultural heritage. The fourth section provides the level of availability of non-interpretive media utilization. The fifth section discusses the finding and result of the data. Lastly, the sixth section is the conclusion of the study.

\subsection{BACKGROUND}

Interpretive media consists of two types: personal and non-personal media [1]. Personal interpretive media utilizes human to assist the tourists for giving the information they need. Whereas, non-personal interpretive media is defined as any kind of media, printed or electronic that does not require human to help tourists at cultural heritage sites. The examples of electronic media are computer simulations; personal stereo guided tours, 3D simulation, virtual reality and recently augmented reality. All of these technologies have been said to bring much more benefits to tourist, by providing multimodal interactive kiosk [7], mobile augmented reality tour guide [8]; [6]; [9] and virtual exhibition [10].

The traditional interpretive media such as, signs, interpretive board, brochures, maps and leaflets need extra fund and does not considered interesting for visitors [8]. Therefore, by using digital media as non-interpretive media, the information of cultural heritage could be conserved through the media; in another word is digital conservation. Digital archiving or digital conservation can be defined as the act of storing collection of cultural heritage information by using digital technology [11]. One of the examples of digital conservation is using augmented reality (AR). $A R$ can be used as an interactive non-personal interpretive media to guide visitors at cultural heritage. Compared to virtual reality (VR), AR offers a better solution to the development of digital conservation in terms of rendering process and computation cost problems since it does not replace the whole real environment [12]. AR also enable user to view both the real and virtual data as well as the present and past scenarios in real time simultaneously [13].

\section{A Non-Personal Interpretive Media Type}

Non-personal interpretive media is a common media at heritage sites. There are two general types of nonpersonal media; (i) visual or printed media and (ii) audio devices. Visual media includes signs, brochures, maps, leaflets and books. Audio device has a self-audio guided tour [1].

The purpose of non-personal interpretive media at a cultural site is to provide tourists with a general information and related history about the site. In this way, it helps tourists to understand the site while they are visiting. Moreover, it is also useful to retain the interest and attention from tourists at a certain spot in the site. This should entertain tourists thereby increasing their enjoyment [14].

As mentioned before, interpretation method is divided into two types: personal (demonstration, personalization and guided tours) and impersonal (signs, displays, self-guided trails, animated models and computer-aided displays) [15]. The impersonal or non-personal interpretive media that become the topic of this study is further explained as follows:

\section{1) Signs}

Signs are one of the effective media to show tourists the information related to the sites (refer to Figure 1). These signs are used to educate, change the perspective or arouse the emotion of tourist [16]. It helps tourists to be aware and look the surrounding more closely [17]. Signs can be in the form of cues on the way to sites or shows the important station in the sites. Signs also should be made of durable material to make them stands for a long time even rain, storm, or the strong light of sun.

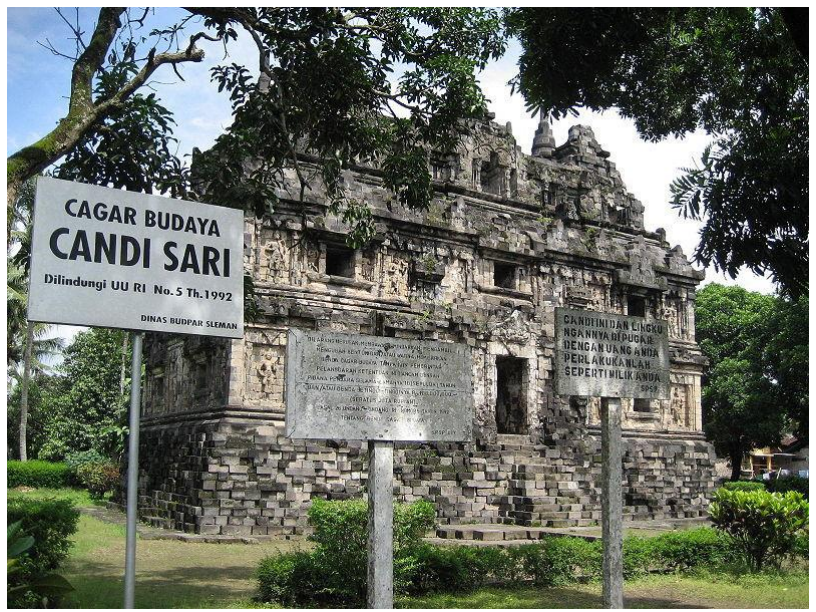

Figure 1 Sign at Sari Temple, Yogyakarta [20]

\section{2) Interpretive Boards}

Interpretive boards use many elements to explain the information to tourists, such as photographs, graphics, and text (refer to Figure 2). These elements may show the pictures of artifact and sculpture of the site during the excavation. Usually, it uses bilingual language to assist tourists to fully understand the information. The board usually is located at the entrance gate to the site. 
So tourists can stop and spend their time for a while to know the general information before entering the area. This is useful to give the simple and quick idea about the specific site. Not all sites have interpretive board, especially the small ones.

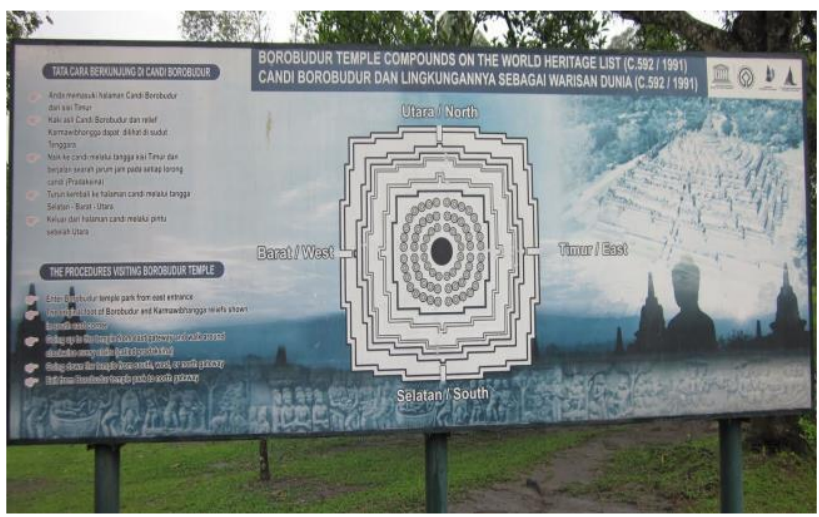

Figure 2 Interpretive board at Brobodur Temple [21]

\section{3) Brochures, maps and leaflets}

Brochures usually explain about the cultural heritage site in a short form for easier and simpler to be carried. Tourist can get the brochures at tourist information center or at the receptionist desk. Maps also have a similar characteristic to brochures, which are usually in the form of folded paper where tourists can see the detail area of the site (refer to Figure 3). These media usually attract tourists with colorful fonts and pictures that will interest tourists to come to the site. Each brochure explains about specific site accordingly.

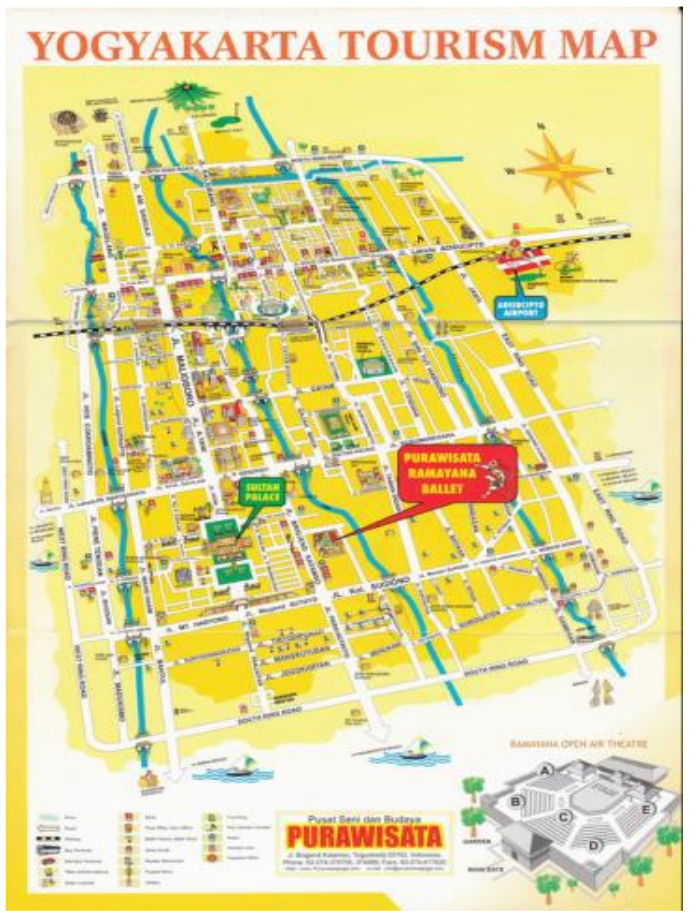

Figure 3 Yogyakarta tourism map [22]
Audio visual room provides the live documentary about the related site. It usually explains about how the heritage site was built. It is not only a video but it shows the detail story about the site. Therefore, it is expected that tourist will have some additional knowledge about the site they visited and will also make them feel entertained (refer to Figure 4).

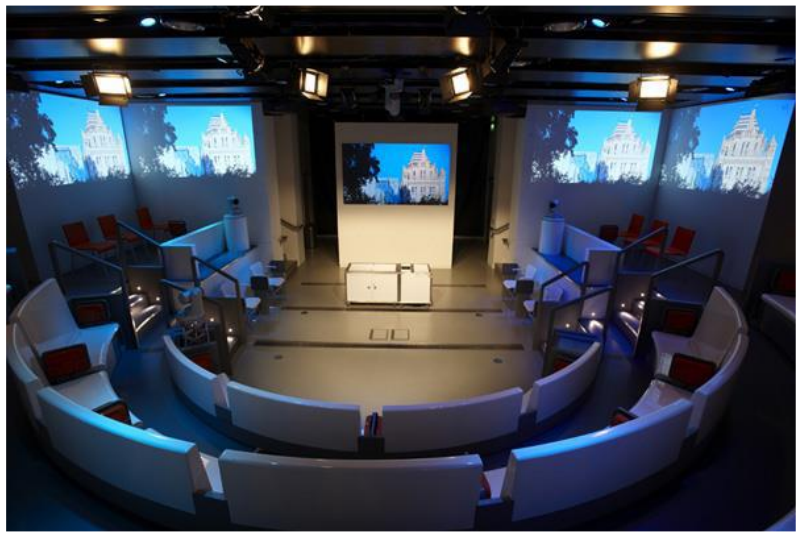

Figure 4 Audio visual room [23]

\section{4) Brochures, maps and leaflets}

AR superimposes the virtual element in the real world. It does not replace the real environment but augments the virtual object to it [18]. AR adds the tourist's perception and interaction with the real world (refer to Figure 5). In cultural heritage, AR can be utilized as the media to visualize the past event to the real world at certain place.

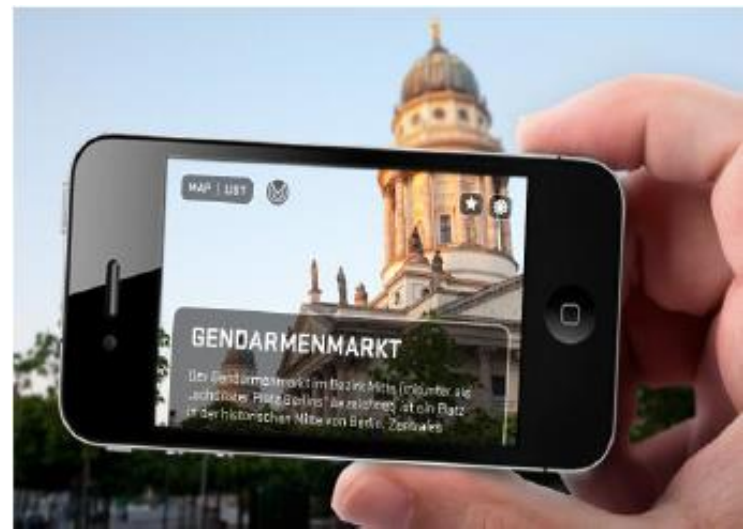

Figure 5 Augmented reality for cultural heritage [24]

\section{B Augmented Reality for Conservation of Cultural Heritage}

For the past ten years, digital conservation using $A R$ technology has been conducted in some countries. There are three projects, ARCHEOGUIDE (2001), LIFEPLUS (2001) and AR-Cathedral (2009) that have 
reconstructed the cultural heritage using $A R$ technology.

1) ARCHEOGUIDE: (Augmented Reality for Cultural Heritage based On-Site Gude)

ARCHEOGUIDE was conducted at Olympia Site, Greece in 2001 [6]. It reconstructs the Olympia Building into 3D simulation that comes along with personalized AR tour guide. Beside conserve the cultural heritage site digitally, the AR tour guide is developed to guide visitors at Olympia site. The tour guide consists of many features such as, monument reconstruction, ancient life simulation, database tool for creating and archiving archaeological multimedia material (refer to Figure 6)

The tour guide allows user to update the information inside the database system. It is also provides a digital map displays the current position of user and direction that user is heading for. While viewing the realistic monument reconstruction, user is allowed having visual contact with the surroundings. Moreover, the audio narration is narrated to give description and additional information about the current visual presentation.

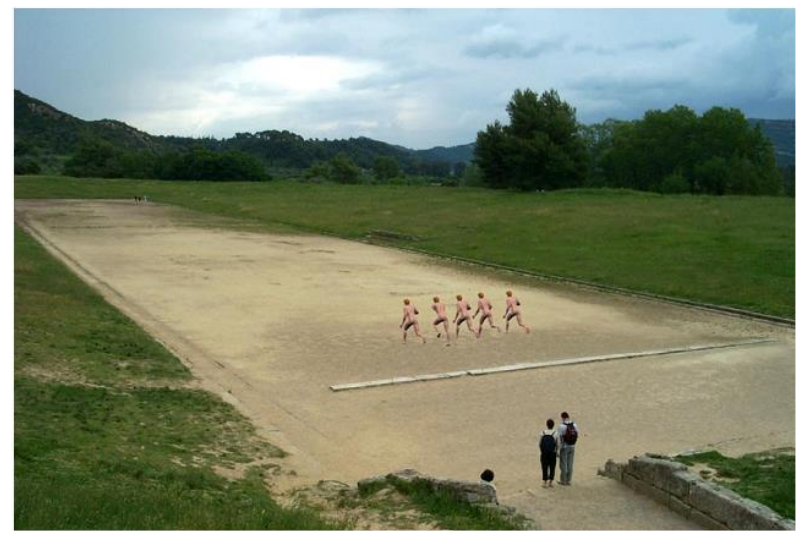

Figure 6 The virtual human simulation in Olympia site

\section{2) LIFEPLUS: Revival Life of Pompeii}

LIFEPLUS project is an innovative 3D reconstruction of ancient frescos paintings by simulations of virtual human, flora and fauna in Pompeii, Italy [19]. It brings the life of Pompeii thousands of years ago into a real visual presentation.

LIFEPLUS recreates the inhabitants of Pompeii following their cloth, hair, skin, facial emotion and speech expression. These virtual characters blend with the real environment and augmented on the same spot where the significant events happened. The project uses story telling as the method to communicate the story of Pompeii to visitors.
It consists of three stories that mostly tell about love stories. Firstly, it starts with a girl who fell in love with a boy who used to read poetry for her. Secondly, it reveals the secret about the best bread in Pompeii. Thirdly, is about another love story. All the objects are visualized in realistic 3D animation to visitors. Figure 7 illustrates one of the scenes in LIFEPLUS Project.

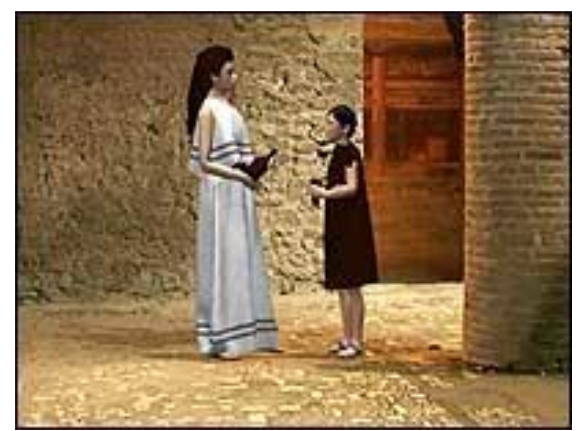

Figure 7 The virtual human simulation in Pompeii $[19$, p.1 1 ]

\section{3) AR-Cathedral}

AR-Cathedral was developed at Valencia Cathedral, Spain. It reconstructs the two features, Baroque vault and Renaissance reredos that stood above the high altar of cathedral centuries ago [13]. The purpose of this project is to bring back the past scenario in the real time as when those artifacts were present in the cathedral. ARCathedral focuses on the user interaction and visitors' understanding about the current situation presented in the site.

The reredos is augmented by the photograph of wooden replica of the former Renaissance silver interior panel (refer to Figure 8). The 3D model of Baroque vault is digitized through the photogrammetry technique to get the accurate measurement of the object. Later on, the Baroque vault is augmented above the altar of Cathedral. This project also held usability test in order to know the user experience factor while using the application. 


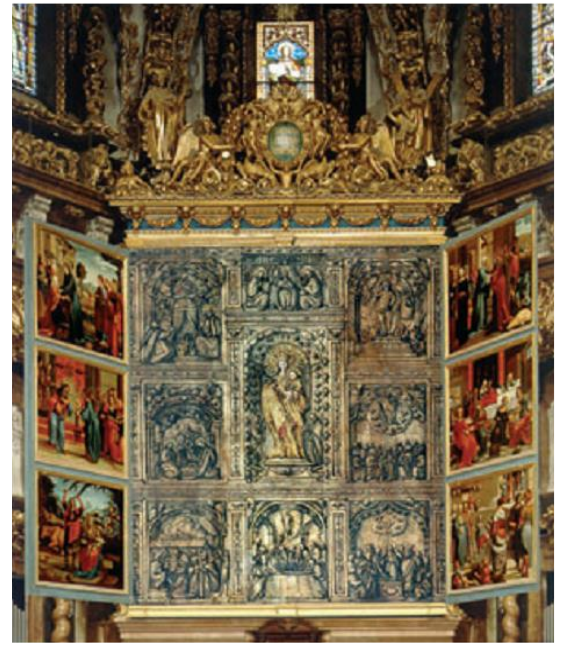

Figure 8 Renaissance reredos augmentation in ARCathedral [13, p.324]

The three projects explained above have done digital conservation using AR technology. ARCEHOGUIDE project reconstructs the monument and ancient life at Olympia Site, Greece. These reconstructions come along with the AR tour guide that is useful to help tourist explore the cultural heritage site. The virtual simulation of human, flora and fauna was done at the Pompeii Cultural Heritage Site. It provides a narrative storytelling with realistic 3D visualization of life at Pompeii. By creating interest and new expectation to visitors, LIFEPLUS has brought the cultural heritage into a better position in the society. The last project, AR-Cathedral, recreates the two important features - Baroque Vault and Renaissance reredos existed in the cathedral long time ago. It has proved the benefit of AR technology to cultural heritage field.

The next section details out the findings that have been documented. The findings result the availability level of non-personal interpretive media at Yogyakarta. Since non-personal interpretive media acts as well as conservation tool, its availability at cultural heritage needs to be investigated.

\subsection{RESEARCH APPROACH}

Twenty cultural heritage sites in Yogyakarta were explored. Data collection was done in June via email communication validated by Archaeological Conservation Centre of Yogyakarta. Firstly, the data collection was done through observation of Yogyakarta cultural heritage pictures on internet. Based on the observation, there were seven temples found located in Yogyakarta along with the interpretive sign and type of media.

The listed finding was sent to Archaeological Conservation Centre of Yogyakarta to be validated. The Archaeological Conservation Centre of Yogyakarta added the list with fourteen temples that makes total number of temples are twenty cultural heritage sites. With that, the availability of nonpersonal interpretive media at cultural heritage sites in Yogyakarta has been validated.

\subsection{RESULTS AND DISCUSSION}

The finding is divided into two categories, interpretive signs and type of media. The categories are driven from the need to know the interpretive media presents at cultural heritage site. The interpretive media or interpretive signs include various types of non-personal interpretive media at Yogyakarta, such as, signs, interpretive boards, maps, audio visual room and interactive video. Further, type of media category explains the media used for the interpretive signs; text, image, audio, video and film.

Table 1 Non-personal Interpretive Media at Yogyakarta (The Archaeological Conservation Centre of Yogyakarta, 2013)

\begin{tabular}{|c|c|c|c|}
\hline Item & Sites/Monuments & $\begin{array}{c}\text { Interpretive } \\
\text { Media }\end{array}$ & Types \\
\hline 1 & $\begin{array}{c}\text { Prambanan } \\
\text { Temple }\end{array}$ & $\begin{array}{l}\text { - Signs } \\
\text { - Interpretive } \\
\text { Board } \\
\text { - Maps } \\
\text { - Audio Visual } \\
\text { Room } \\
\end{array}$ & $\begin{array}{l}\text { Text, image, } \\
\text { Audio Video }\end{array}$ \\
\hline 2 & $\begin{array}{l}\text { Keraton Ratu } \\
\text { Boko Complex }\end{array}$ & $\begin{array}{l}\text { - Signs } \\
\text { - Interpretive } \\
\text { Board } \\
\text { - Maps } \\
\end{array}$ & $\begin{array}{c}\text { Text, Image, } \\
\text { Audio Video, } \\
\text { Film }\end{array}$ \\
\hline 3 & ljo Temple & $\begin{array}{l}\text { - Signs } \\
\text { - Interpretive } \\
\text { Board } \\
\text { - Maps } \\
\end{array}$ & Text, Image \\
\hline 4 & Barong Temple & $\begin{array}{l}\text { - Signs } \\
\text { - Interpretive } \\
\text { Board } \\
\end{array}$ & Text, Image \\
\hline 5 & $\begin{array}{l}\text { Banyunibo } \\
\text { Temple }\end{array}$ & $\begin{array}{l}\text { - Signs } \\
\text { - Interpretive } \\
\text { Board } \\
\end{array}$ & Text, Image \\
\hline 6 & Sari Temple & $\begin{array}{l}\text { - Signs } \\
\text { - Interpretive } \\
\text { Board } \\
\end{array}$ & Text, Image \\
\hline 7 & Kalasan Temple & $\begin{array}{l}\text { - Signs } \\
\text { - Interpretive } \\
\text { Board } \\
\end{array}$ & Text, Image \\
\hline 8 & $\begin{array}{l}\text { Sambisari } \\
\text { Temple }\end{array}$ & $\begin{array}{l}\text { - Signs } \\
\text { - Interpretive } \\
\text { Board } \\
\text { - Audio Visual } \\
\text { Room } \\
\end{array}$ & Text, Image \\
\hline 9 & Kedulan Temple & - Signs & Text \\
\hline 10 & Gebang Temple & - Signs & Text \\
\hline 11 & Kadisoka Temple & - Signs & Text \\
\hline 12 & $\begin{array}{c}\text { Gampingan } \\
\text { Temple }\end{array}$ & - Signs & Text \\
\hline 13 & Mantup Temple & - Signs & Text \\
\hline
\end{tabular}




\begin{tabular}{|c|c|c|c|}
\hline Item & Sites/Monuments & $\begin{array}{c}\text { Interpretive } \\
\text { Media }\end{array}$ & Types \\
\hline 14 & $\begin{array}{l}\text { Morangan } \\
\text { Temple }\end{array}$ & $\begin{array}{l}\text { - Signs } \\
\text { - Interpretive } \\
\text { Board }\end{array}$ & Text, Image \\
\hline 15 & $\begin{array}{l}\text { Klodangan } \\
\text { Temple }\end{array}$ & - Signs & Text \\
\hline 16 & $\begin{array}{l}\text { Dawangsari } \\
\text { Temple }\end{array}$ & - Signs & Text \\
\hline 17 & $\begin{array}{l}\text { Plembutan } \\
\text { Temple }\end{array}$ & $\begin{array}{l}\text { - Signs } \\
\text { - Interpretive } \\
\text { Board } \\
\end{array}$ & Text, Image \\
\hline 18 & Risan Temple & - Signs & Text, Image \\
\hline 19 & $\begin{array}{l}\text { Kimpulan } \\
\text { Temple }\end{array}$ & $\begin{array}{l}\text { - Signs } \\
\text { - Interpretive } \\
\text { Board } \\
\text { - Audio Visual } \\
\text { Room } \\
\text { - Interactive } \\
\text { Video }\end{array}$ & $\begin{array}{l}\text { Text, Image, } \\
\text { Audio Video }\end{array}$ \\
\hline 20 & Palgading Site & - Signs & Text \\
\hline
\end{tabular}

Table 1 shows that none of AR is implemented in Yogyakarta. However, the Prambanan Temple, Keraton Ratu Boko Complex and Kimpulan Temple are the three sites of twenty cultural heritage sites in Yogyakarta that provides multimedia presentation in Yogyakarta cultural heritage site. The multimedia presentations currently used are audio visual room, film and interactive video. The other temples are mostly equipped by signs only, and sign and interpretive board. This indicates that text and image are used by majority of the cultural heritage buildings as means to share the information at the heritage sites.

Referring to Figure 9, it is identified that the signs have $100 \%$ of availability in Yogyakarta cultural heritage site. It is followed by interpretive board with $55 \%$, maps and audio visual room with both percentage, $15 \%$.

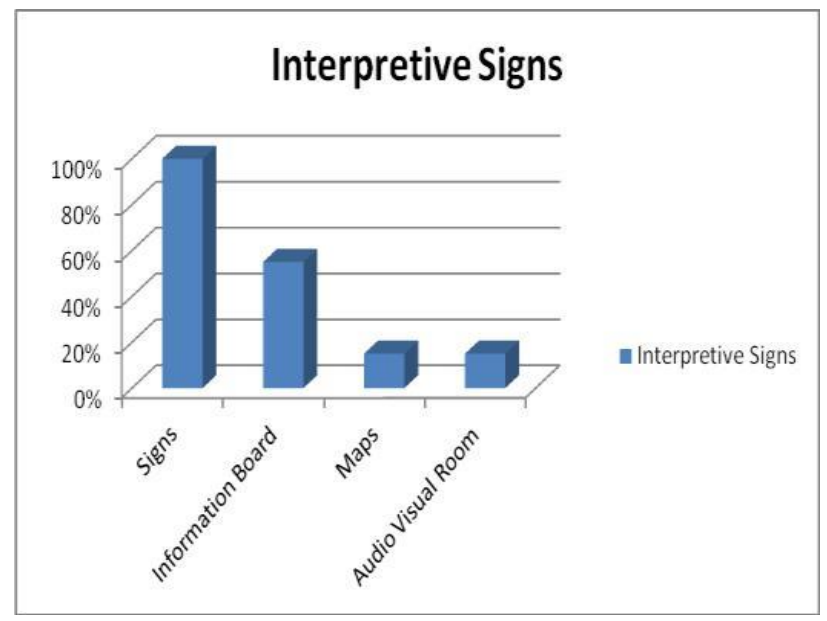

Figure 9 Percentage of non-personal interpretive media at Yogyakarta
The data explains that all cultural heritage sites in Yogyakarta have signs as non-personal interpretive media type. Signs are common at cultural heritage sites; they use it as the name of the site and the direction. Interpretive boards are provided by half of total number of cultural heritage sites. It is usually owned by large and medium cultural heritage sites. However, maps and audio visual room get the lowest percentage, $15 \%$. Audio visual room is owned only by few sites due to its expensive cost.

Text is utilized by all cultural heritage sites in Yogyakarta, it can be seen by the $100 \%$ percentage (refer to Figure 10). The image is provided by $60 \%$ of all cultural heritage sites. It is used by half of total number of cultural heritage sites as type of media. Audio and video obtain the lowest percentage of all types of media, $15 \%$. It is the scarcest type of media at Yogyakarta cultural heritage sites.

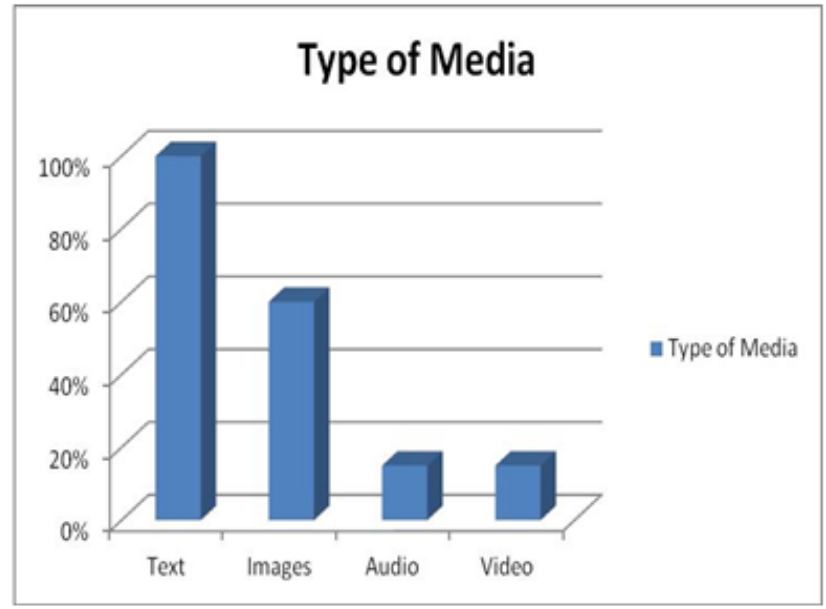

Figure 10 Percentage of type of media at Yogyakarta

The limited availability of digital media exists at Yogyakarta is due to outdated guidebook, the Technical Manual Preservation of Archeological Heritage which has been the main reference since 1996. This guidebook provides guidance to the archeological centre as to how the cultural heritage can be conserved and preserved at best. In addition, most of the cultural heritage site is located in the remote area that lacks of electricity and infrastructure. It is difficult to implement the digital media which needs the complete infrastructure material and technology. However, the digital media implementation becomes the future plan for cultural heritage site at Yogyakarta.

\subsection{CONCLUSION}

From the findings, it is proved that there is lack of digital media utilization at Yogyakarta cultural heritage site. The traditional media still dominates the type of non-personal interpretive media. The findings of this study provide evidences of the usage of digital 
media at cultural heritage sites. Without any type of digital media, such as AR, conservation is hard to be implemented. Since conservation is important, it is suggested that digital interpretive media need to be provided at cultural heritage sites.

The future direction of this study is to implement AR as the non-interpretive media and investigate the impact for interpretation to visitors at Yogyakarta Cultural Heritage Sites.

\section{Acknowledgement}

I acknowledge the Archaeological Conservation Centre of Yogyakarta whom has helped me to conduct the survey through the online data collection and Universiti Utara Malaysia for the research grant.

\section{References}

[1] Timothy, D. J. and S. W. Boyd. 2003. Heritage Tourism Pearson Education Limited Ltd.

[2] ICOMOS. 2013. Interpretation and Presentation of Cultural Heritage Sites. [Online]. From: http://international.icomos.org/charters/interpretation_e. pdf. [Accessed on 4 July 2013].

[3] Mutis, T. and W. Arafah. 2012. Tourism Growth Strategy and Its Impact in Indonesia Economy. In International Conference of Business and Management. 74(74): 656663.

[4] Sodangi, M., A. Idrus and F. Khamidi. 2010. Maintenance Management Framework for Conservation of Heritage Buildings in Malaysia. Mod. Appl. Sci. 4(11): 66-77.

[5] Timothy, D.J. 2007. Introduction. In D.J. Timothy (ed.). Managing Heritage and Cultural Tourism Resources. Hampshire, England: Ashgate Publishing Limited.

[6] Vlahakis, V., J. Karigiannis, M. Tsotros, M. Gounaris, L. Almeida, D. Stricker, T. Gleve, I.T. Christou, R. Carlucci and N. loannidis. 2001. ARCHEOGUIDE: First Results of an Augmented Reality, Mobile Computing System in Cultural Heritage Sites. In Conference on Virtual Reality, Archaeology and Virtual Heritage (VAST). Athens, Greece. 28-30 November 2001. 131-140.

[7] Liarokapis, F., S. Sylaiou and D. Mountain. 2008. Personalizing Virtual and Augmented Reality for Cultural Heritage Indoor and Outdoor Experiences. In Proceedings of the 9th International Conference on Virtual Reality, Archaeology and Cultural Heritage (VAST '08). Braga, Portugal. 2-6 December 2008. 55-62.

[8] Seo, B., K. Kim and J. I. Park. 2011. Augmented Realitybased On-Site Tour Guide: A Study in Gyeongbokgung. In R. Koch and F. Huang (eds.). Computer Vision-ACCV 2010 Workshops. Springer Berlin Heidelberg.
[9] iTACITUS. 2012. iTACITUS-Intelligent Tourism and Cultural Information through Ubiqutuous Service. [Online]. From: itacitus.org. [Accessed on 7 June 2012].

[10] Walczak, K., W. Cellary and M. White. 2006. Virtual Museum Exhibitions. Computer (Long. Beach. Calif). 39(3): 93-95.

[11] Gunarto, H. 2007. Digital Preservation of Borobudur World Heritage. J. Ritsumeikan Stud. Lang. Cult. 19(2): 263-278.

[12] Noh, Z., M. S. Sunar and Z. Pan. 2009. A Review on Augmented Reality for Virtual Heritage. In M. Chang, R. Kuo, Kinshuk, G.-D. Chen and M. Hirose (eds.). Learning by Playing. Game-based Education System Design and Development. Springer Berlin Heidelberg.

[13] Portalés, C., J. L. Lerma and C. Perez. 2009. Photogrammetry and Augmented Reality for Cultural Heritage Applications. Photogramm. Rec. 24(128): 316331.

[14] Light, D. 2007. Visitors' Use of Interpretive Media at Heritage Sites. In D.J. Timothy (ed.). Managing Heritage and Cultural Tourism Resources. Hampshire, England: Ashgate Publishing Limited.

[15] Puczkó, L. 1998. Interpretation in Cultural Tourism. In M.K. Smith and M. Robinson (eds.). Cultural Tourism in A Changing World Politics, Participation and (Re)presentation. Clevedon, UK: Channel View Publication.

[16] US Forest Service. 2013. Interpretive Signs. [Online]. From: http://www.fs.fed.us/outdoors/naturewatch/implementati on/Interpretive-Signs/Interpretive-Sign-Design.PDF. [Accessed on 2 April 2013].

[17] Honig, M. 2000. Interpretive Signs. [Online]. From: http://www.sabonet.org.za/downloads/9_garden_come_ alive/chapter_5. pdf. [Accessed on 2 April 2013].

[18] Azuma, R. T. 1997. A Survey of Augmented Reality. Presence: Teleoperators and Virtual Environment. 6(4): 355-385.

[19] Papagiannakis, G., M. Ponder, T. Molet and S. Kshirsagar. 2002. LIFEPLUS: Revival of Life in Ancient Pompeii. In Proceedings of 8 th International Conference on Virtual Systems and Multimedia (VSMM ). Gyeongrj, Korea. 25-27 September 2002. 1-11.

[20] Ipank. 2012. Candi Sari, Bangunan Budhaistis Bagian Candi Kalasan. [Online]. From: http://yogyakarta.panduanwisata.com/wisata-sejarah2/candi-sari- bangunan-budhaistis-bagian-candikalasan/. [Accessed on 25 Oct. 2013].

[21] Farid. 2011. Kisah Motor Kapcai. [Blog Entry]. From: http://motor-kapcai.blogspot.com/2011/07/candiborobudur.html. [Accessed on 25 Oct. 2013].

[22] Fadli. 2012. A Travel Series and Vlog by A Sarawakian. [Blog Entry]. From: http://www.mytravellicious.com.

[23] Wei, D. and W. Russel. 2010. New Work: Attenborough Studio at The Natural History Museum. [Blog Entry]. From: http://new.pentagram.com/2010/11/william-russell-anddaniel wei/. [Accessed on 30 Nov 2010].

[24] Smart Mobile Factory. Augmented Reality. [Online]. From: http://smartmobilefactory.com/en/applicationdevelopment/components/augmented-reality.html. 